\title{
Persepsi konsumen dan faktor-faktor yang mempengaruhi keputusan pembelian beras premium
}

\author{
Mas'ud Mahendra ${ }^{1}$, Wenny Mamilianti ${ }^{*}$ \\ ${ }^{1}$ Department of Agribusiness, Faculty of Agriculture University of Yudharta Pasuruan, Pasuruan, Indonesia \\ *E-mail: wennymfp@yudharta.ac.id
}

\begin{abstract}
Increasing rice consumption in Indonesia provides a great opportunity in the rice business. Rice's business development is marked by the emergence of rice producers with various brands and qualities. Improving the standard of living of the Indonesian people also affects consumer behavior in choosing rice to be consumed. This change in consumer behavior is responded by rice producers by producing super quality rice or often called premium rice. The rise of premium rice sales now needs a study of consumer behavior towards premium rice purchasing decisions. This study aims to analyze consumers' perceptions of premium rice and analyze the factors that influence consumer behavior in purchasing premium rice. The study's location was determined intentionally in the city of Pasuruan, and respondents were 100 rice consumers through convenience sampling. The method of data analysis uses tabulation description analysis and regression Logit models. The results showed consumers' perceptions of premium rice by $47 \%$ the price of premium rice is higher, $53 \%$ the color is perfect, $56 \%$ expressed better dexterity, $51 \%$ better aroma, $47 \%$ endurance as well as other rice, $78 \%$ uniformity of grain better, and $49 \%$ stated that cleanliness was the same as other rice. Consumer perception of the belief in premium rice that $47 \%$ of consumers stated that premium rice is better than medium rice. The factors that significantly influence the purchase of premium rice are education, income, and the number of household members.
\end{abstract}

Keywords: consumer perception, premium rice, purchase decision

Abstrak. Peningkatan konsumsi beras di Indonesia memberikan peluang besar dalam bisnis perberasan. Perkembangan bisnis perberasan ditandai munculnya produsen-produsen beras dengan berbagai merk dan kualitas. Peningkatan taraf hidup masyarakat Indonesia juga mempengaruhi perilaku konsumen dalam memilih beras yang di konsumsi. Perubahan perilaku konsumen ini direspon oleh produsen beras dengan memproduksi beras berkualitas super atau sering disebut beras premium. Maraknya penjualan beras premium sekarang ini perlu adanya kajian tentang perilaku konsumen terhadap keputusan pembelian beras premium. Tujuan penelitian ini adalah menganalisis persepsi konsumen terhadap beras premium dan menganalisis faktor-faktor yang mempengaruhi perilaku konsumen dalam pembelian beras premium. Lokasi penelitian ditentukan secara sengaja yaitu di kota Pasuruan dan responden adalah konsumen beras sebanyak 100 orang melalui convenience sampling. Metode analisis data menggunakan analisis deskripsi tabulasi dan regresi model Logit. Hasil penelitian menunjukkan persepsi konsumen terhadap beras premium sebesar $47 \%$ harga beras premium lebih mahal, 53\% warna sangat baik, 56\% menyatakan kepulenan lebih baik, $51 \%$ aroma lebih baik, $47 \%$ daya tahan sama baik dengan beras lainnya, $78 \%$ keseragaman bulir lebih baik, dan $49 \%$ menyatakan bahwa kebersihan sama saja dengan beras lainnya. Persepsi konsumen terhadap kepercayaan terhadap beras premium, bahwa $47 \%$ konsumen menyatakan bahwa beras premium lebih baik daripada beras medium. Faktor-faktor yang berpengaruh signifikan terhadap keputusan pembelian beras premium adalah pendidikan, pendapatan dan jumlah anggota keluarga.

Kata kunci: beras premium, keputusan pembelian, persepsi konsumen 


\section{PENDAHULUAN}

Indonesia adalah salah satu produsen beras terbesar di Asia setelah India, Vietnam, dan beberapa negara Asia lainnya. Jumlah penduduk Indonesia saat ini kurang lebih 260 juta orang dan sebagian besar makanan pokoknya adalah beras (Khoiriyah, dkk., 2020, Sa'diyah, dkk., 2019). Oleh karena itu pemerintah sangat memperhatikan usahatani padi dan bisnis perberasan. Tingkat konsumsi beras masyarakat Indonesia pada tahun 2013 adalah 90,62 kg/kapita/tathun, tahun 2014 sebesar 97,204 $\mathrm{kg} / \mathrm{kapita} / \mathrm{tahun}$, sedangkan pada tahun 2015 sebesar 98,05 kg/kapita/tahun (BPS, 2017) dan pada tahun 2016, berdasarkan data Susenas 2016, tingkat konsumsi beras rumah tangga di lima level kemiskinan di Indonesia sebesar 21,09 gr/kapita/hari (Khoiriyah, dkk., 2020). Dari sini bisa dilihat bahwa trend konsumsi beras masyarakat Indonesia semakin meningkat dari tahun ke tahun.

Tingkat konsumsi beras yang cenderung meningkat menjadi peluang bisnis yang baik di bidang perberasan. Saat ini telah banyak produsen-produsen beras dengan berbagai merk menghiasi pasar perberasan di Indonesia. Ditunjang lagi dengan pertumbuhan ekonomi Indonesia yang meningkat berdampak pada peningkatan taraf hidup masyarakat yang ditunjukkan peningkatan pendapatan rumah tangga. Peningkatan pendapatan akan berpengaruh terhadap pola konsumsi beras. Pola konsumsi beras ini ditunjukkan dengan keputusan untuk memilih beras yang layak dikonsumsi. Konsumen akan memilih beras yang memiliki kualitas lebih baik untuk meningkatkan kepuasannya. Hal ini sesuai dengan penelitian Prakarsa, dkk. (2010), bahwa perubahan tingkat pendapatan dan pendidikan mendorong perubahan preferensi konsumen terhadap produk. Saat ini konsumen sudah berubah pola konsumsi terhadap beras yaitu lebih memilih beras yang berkualitas. Rahmawati (2013) menjelaskan bahwa tingkat konsumsi beras dipengaruhi oleh harga beras, jumlah anggota keluarga dan pendapatan.

Jenis beras yang ada di pasar berdasarkan informasi Badan Standardisasi Nasional (BSN, 2015), beras terbagi atas 4 klasifikasi Standar Nasional Indonesia (SNI) mutu beras, yakni premium, medium I, medium II, dan medium III. Dari klasifikasi tersebut tentunya kualitas beras premium yang paling tinggi yaitu ditandai dengan butir kepala hampir 100\%, kadar air 14\%, derajat sosoh (bebas kulit ari) mencapai $100 \%$, warna lebih cerah dan biasanya aroma lebih harum. Beras premium yang memiliki kualitas yang bagus menjadi pasar potensial di dunia perberasan karena adanya perubahan pola konsumsi. Peluang bisnis ini menjadi incaran bagi para produsen beras. Dan sekarang produsen beras premium sudah banyak bermunculan dengan berbagai merk dan kemasan yang menarik. Persaingan semakin berat dan produsen untuk mendapatkan keuntungan harus melakukan berbagai strategi pemasaran. Salah satu strategi yang bisa dilakukan antara lain, produsen beras premium agar memperhatikan kualitas produk dan harga beras, hal ini seperti yang disampaikan oleh Puspitasari, dkk. (2018) bahwa kualitas beras dan kesesuaian harga meningkatkan penjualan beras premium di Sulawesi Utara dan Gorontalo. Hasil penelitian ini menggambarkan bahwa kualitas beras dan harga menjadi faktor penentu konsumen untuk memutuskan pembelian beras premium. Mufidah, dkk. (2018) menyatakan bahwa volume penjualan beras premium Bulog di daerah Kedu tidak hanya dipengaruhi oleh kualitas produk dan harga saat itu namun juga dipengaruhi oleh besar kecilnya kebutuhan masyarakat terhadap beras premium. Hal ini dilihat dari jenis konsumen, ada konsumen rumah tangga, catering dan restoran, Konsumen rumah tangga membeli untuk kebutuhan keluarga, konsumen catering membeli dalam jumlah banyak untuk keperluan hajatan/resepsi atau lainnya, konsumen restoran membeli untuk kebutuhan penjualan direstorannya.

Dengan semakin maraknya penjualan beras premium sekarang ini perlu adanya kajian tentang perilaku konsumen beras terhadap keputusan pembelian beras premium. Hal ini didasarkan beberapa penelitian yang menyatakan bahwa pengetahuan dan pemahaman konsumen terhadap kualitas beras masih terbatas pada harga, rasa dan penampakan luar. Hal ini seperti diutarakan Prakarsa, dkk. (2010). Selain itu My et al. (2017) mengatakan bahwa pengetahuan konsumen di Vietnam Utara terhadap produk beras berkulitas dan bersertifikat masih lemah. Selain itu perlu dikaji tentang faktor-faktor yang mempengaruhi keputusan konsumen terhadap konsumsi beras premium. Hal ini didasarkan bahwa apakah benar kenaikan pendapatan masyarakat mempengaruhi keputusan pembelian beras. Selain itu harga beras premium apakah tidak menjadi pertimbangan bagi konsumen untuk membeli beras premium. Dengan penelitian ini diharapkan mendapatkan beberapa informasi penting yang dapat dipertimbangkan oleh pemerintah dalam mengambil kebijakan dan informasi bagi produsen beras premium tentang perilaku konsumen beras premium di Indonesia. 


\section{METODE}

Penentuan lokasi dilakukan secara sengaja (purposive) di kota Pasuruan dengan pertimbangan bahwa beras premium telah banyak diperdagangkan di Kota Pasuruan. Kota Pasuruan termasuk wilayah industri yang memiliki potensi besar pasar beras premium. Sampel dalam penelitian ini adalah konsumen yang mengetahui dan atau pernah membeli beras premium. Penelitian ini adalah penelitian survey dimana dalam teknik pengambilan data dilakukan melalui wawancara kepada sampel terpilih dan observasi lapang. Sampel dalam penelitian ditentukan berdasarkan metode convenience sampling dimana responden dipilih berdasarkan kemudahan atau kenyamanan mendapatkannya. Dengan kata lain sampel didapat karena berada pada tempat dan waktu yang tepat, yaitu pada saat sampel berada di tempat penjualan dan saat belanja beras dan memang bersedia menjadi responden. Jumlah sampel ditentukan sengaja yaitu berjumlah 100 orang.

Metode analisis data menggunakan metode tabulasi data dan regresi model Logit. Metode tabulasi data untuk menganalisis persepsi konsumen terhadap beras premium dan regresi model Logit digunakan untuk menganalisis faktor-faktor yang mempengaruhi keputusan pembelian beras premium. Tabulasi data untuk melihat persepsi konsumen terhadap beras premium dilakukan pada beberapa variabel yaitu harga, kebersihan, warna, kepulenan, keseragaman bulir, aroma, daya tahan beras dan kepercayaan terhadap beras premium. Analisis model regresi Logit digunakan untuk menentukan faktor-faktor yang mempengaruhi keputusan pembelian beras premium. Faktor-faktor yang dianalisis adalah harga beras dan karakteristik responden/sampel meliputi usia, pendidikan, pendapatan, jumlah anggota keluarga, dan persepsi konsumen terhadap beras premium. Adapun model regresi Logit dalam penelitian ini dirumuskan sebagai berikut:

$$
\mathrm{Z}=\ln \frac{P i}{(1-P i)}=\beta_{0}+\beta_{1} \mathrm{x}_{1}+\beta_{2} \mathrm{x}_{2}+\beta_{3} \mathrm{x}_{3}+\beta_{4} \mathrm{x}_{4}+\beta_{5} \mathrm{x}_{5}+\beta_{6} \mathrm{x}_{6+} \varepsilon
$$

Keterangan:

$\mathrm{Z}$ : keputusan pembelian beras diukur dengan 1 jika memutuskan membeli, 0 jika tidak

$\beta_{0}$ : kontanta dan $\beta_{\mathrm{i}}$ : koefisien parameter

$\mathrm{x}_{1}$ : Harga beras premium, harga beras pada saat dilakukan penelitian diukur dengan ( $\left.\mathrm{Rp}\right)$

$\mathrm{x}_{2}:$ usia/umur responden saat dilakukan wawancara diukur dengan tahun

$\mathrm{x}_{3}$ : pendidikan responden diukur dengan tahun, jika pendidikan $\mathrm{SD}=6$ tahun, $\mathrm{SMP}=9$ tahun, SMA = 12 tahun, D3= 15 tahun dan Sarjana 16 tahun

$\mathrm{x}_{4}$ : pendapatan, jumlah pendapatan yang diperoleh selama satu bulan (Rp)

$\mathrm{x}_{5}$ : jumlah anggota keluarga, jumlah anggota keluarga yang ditanggung dalam satu rumah tangga (orang)

$\mathrm{x}_{6}$ : persepsi beras premium dibandingkan dengan beras lainnya, bernilai 1 jika responden menyatakan kualitas bagus dan 0 jika kurang bagus.

$\varepsilon$ : standart error.

Untuk mengetahui seberapa besar independent variable (x) mempengaruhi dependent variable $(\mathrm{Z})$ maka model diuji secara serempak menggunakan Goodness of fit test berdasarkan tes likelihood ratio (DeMaris, 1992) sebagai berikut:

1. Uji Chi-Square yaitu untuk menguji seberapa penting variabel independen dapat menduga variabel dependen dalam model. Hipotesis yang diajukan adalah:

$\mathrm{H}_{0}: \beta_{1}=\beta_{2}=, \ldots . ., \beta_{6}=0$

$\mathrm{H} 1$ : paling tidak ada satu nilai $\beta_{\mathrm{i}}$ tidak sama dengan nol.

Kriteria keputusannya adalah :

- Bila $\chi^{2}$ hitung $\leq \chi^{2}$ tabel $(0,01 ; 6) \rightarrow$ Ho diterima, artinya secara serempak semua variabel bebas tidak mampu menjelaskan keputusan pembelian beras premium, atau model tidak fit.

- Bila ${ }_{\text {hitung }}^{2}>\quad \chi_{\text {tabel }(0,01 ; 6)}^{2} \rightarrow \mathrm{H}_{1}$ artinya secara serempak semua variabel bebas mampu menjelaskan keputusan pembelian beras premium, atau dengan kata lain model logit faktor-faktor yang mempengaruhi pembelian beras premium tersebut fit (sesuai).

2. Uji Goodness of fit yaitu membandingkan hasil nilai goodness of fit bersangkutan dengan $\chi^{2}$ tabel. Hipotesis yang diajukan adalah: 
Ho : tidak ada perbedaan antara data hasil observasi dengan hasil prediksi

$\mathrm{H}_{1}$ : ada perbedaan antara data hasil observasi dengan hasil prediksi

Kriteria keputusannya adalah :

- Bila nilai goodness of fit $\leq \chi^{2}$ tabel $(0,01 ; 100) \rightarrow \mathrm{H}_{\mathrm{o}}$ diterima, artinya tidak ada perbedaan antara hasil observasi dengan hasil prediksi, atau dengan kata lain model tersebut fit (sesuai).

- Bila nilai goodness of fit $>\chi^{2}$ tabel $(0,01 ; 100) \rightarrow \mathrm{H}_{1}$ diterima, ada perbedaan antara hasil observasi dengan hasil prediksi. Artinya parameter yang dihasilkan tidak dapat digunakan untuk menduga pengaruh variabel faktor penyebab terhadap keputusan migrasi ke Malaysia.

3. Membandingkan nilai likelihood observed (-2log likelihood $\left.d_{l}\right)$ dengan $\chi^{2}$ tabel $(0,01 ; 100)$. Hipotesis yang diajukan adalah:

- Bila nilai -2log likelihood $d_{1} \leq \chi^{2}$ tabel $(0,01 ; 100) \rightarrow \mathrm{H}_{\mathrm{o}}$ diterima, artinya nilai liketihood observed tidak berbeda dengan 1 , atau dengan kata lain model tersebut fit (sesuai)'

- Bila nilai -2log likelihood $d_{1}>\chi_{\text {tabel(0,01;100) }}^{2} \rightarrow \mathrm{H}_{1}$ diterima, artinya nilai likltihood observed berbeda dengan 1, atau dengan kata lain model tersebut tidak fit (tidak sesuai).

Untuk mengetahui seberapa besar faktor penyebab mampu menjelaskan peluang keputusan pembelian beras premium digunakan formula sebagai berikut (DeMaris, 1992):

$\mathrm{R}_{\mathrm{L}}^{2}=\frac{-2 \log L_{0}-\left(-2 \log L_{1}\right)}{-2 \log L_{0}}$

Selanjutnya untuk mengetahui pengaruh masing-masing faktor mempengaruhi peluang keputusan pembelian beras premium $\left(\mathrm{Z}_{\mathrm{i}}\right)$ dilakukan uji parsial (uji t) sebagai berikut:

$t_{\text {hitung }}=\frac{\beta i}{\operatorname{se}(\beta i)} t_{\text {tabel }}(\alpha / 2)(n-k) d b$

keterangan:

$ß \mathrm{i}=$ koefisien regresi logit variabel ke-i, dan

$\beta \mathrm{i}=$ standart error dari koefisien regresi logit variabel ke-i

$=$ varian $\beta \mathrm{i}$

Hipotesis yang diajukan sebagai berikut:

$\mathrm{H}_{0}: \beta_{\mathrm{i}}=0$

$\mathrm{H}_{1}: \beta_{\mathrm{i} \neq} 0$

Kaidah keputusannya adalah:

- Bila $t_{\text {hitung }} \leq \mathrm{t}_{\text {tabel }}(\alpha / 2 ; \mathrm{n}-\mathrm{k}) \rightarrow$ Ho diterima, berarti faktor penyebab ke-I tidak berpengaruh terhadap peluang keputusan pembelian beras premium, dan.

- Bila $t_{\text {hitung }}>t_{\text {tabel }}(\alpha / 2 ; n-k) \rightarrow H_{1}$ diterima, berarti faktor penyebab ke-I berpengaruh terhadap peluang keputusan pembelian beras premium.

\section{HASIL DAN PEMBAHASAN}

\subsection{Persepsi konsumen terhadap beras premium}

Penilaian persepsi konsumen terhadap beras premium dilakukan dengan membandingkan harga, kualitas (warna, kepulenan, aroma, daya tahan, keseragaman bulir beras, dan kebersihan), dan kepercayaan terhadap beras premium.

\section{a. $\quad$ Persepsi konsumen terhadap harga beras premium}

Dalam mengukur persepsi konsumen terhadap harga beras premium dilakukan dengan cara mengajukan pertanyaan yang terdiri dari tiga jawaban yaitu: lebih mahal, sama saja, dan lebih murah.

Tabel 1. Persepsi Konsumen Terhadap Harga Beras Premium

\begin{tabular}{lcc}
\hline Harga Beras Premium & $\begin{array}{c}\text { Jumlah } \\
\text { (orang) }\end{array}$ & $\begin{array}{c}\text { Presentase } \\
(\%)\end{array}$ \\
\hline Lebih Mahal & 47 & 47 \\
Sama Saja & 32 & 32 \\
Lebih Murah & 21 & 21 \\
Total & 100 & 100 \\
\hline Sumber: Data primer, diolah 2018. & &
\end{tabular}


Mengacu pada Tabel 1 dapat disimpulkan bahwa sebanyak 47 orang (47\%) responden menganggap bahwa harga beras premium lebih mahal dibandingkan dengan harga beras medium. 32 orang $(32 \%)$ responden menganggap bahwa harga beras premium sama saja dengan harga beras jenis lain seperti beras medium. Sebanyak 21 orang $(21 \%)$ responden menganggap bahwa harga beras premium lebih murah dibandingkan dengan harga beras medium. Harga beras premium di lokasi penelitian berkisar antara Rp.11.000 - Rp.13.000. Rata-rata konsumen membeli beras premium dengan harga Rp.12.000 dengan alasan harga terjangkau dengan kualitas yang lumayan bagus. Konsumen membeli beras premium sebagian besar di supermarket meskipun di toko-toko juga telah tersedia. Konsumen yang menyatakan beras premium lebih murah dari harga beras yang lain karena mereka membandingkan dengan harga eceran harga beras biasa di toko meskipun selisihnya sedikit mereka menyatakan bahwa harga beras premium lebih murah. Selain itu konsumen menyatakan harga beras premium lebih murah karena mereka mendapatkan manfaat yang lebih dari pada beras biasa.

\section{b. Persepsi Konsumen Terhadap Kualitas Beras Premium}

Pengukuran persepsi konsumen terhadap kualitas produk beras premium dilakukan dengan cara mengajukan pertanyaan yang jawabannya lebih baik, sama baik, atau lebih buruk bila dibandingkan dengan kualitas beras jenis medium. Penilaian persepsi konsumen terhadap kualitas beras premium menggunakan beberapa indikator antara lain: warna, kepulenan, aroma, daya tahan, keseragaman bulir beras, dan kebersihan.

Tabel 2. Persepsi Konsumen terhadap Kualitas Beras Premium

\begin{tabular}{lcc}
\hline Kualitas beras premium & $\begin{array}{c}\text { Jumlah } \\
\text { (Orang) }\end{array}$ & $\begin{array}{c}\text { Presentase } \\
(\boldsymbol{\%})\end{array}$ \\
\hline Warna & 36 & 36 \\
Lebih Baik & 53 & 53 \\
Sama Baik & 11 & 11 \\
Lebih Buruk & & \\
Kepulenan & 56 & 56 \\
Lebih Baik & 37 & 37 \\
Sama Baik & 7 & 7 \\
Lebih Buruk & & \\
Aroma & 51 & 51 \\
Lebih Baik & 40 & 90 \\
Sama Baik & 9 & 41 \\
Lebih Buruk & & 47 \\
Daya Tahan & 41 & 12 \\
Lebih Baik & 47 & 78 \\
Sama Baik & 12 & 22 \\
Lebih Buruk & & 0 \\
Keseragaman Bulir Beras & 78 & \\
Lebih Baik & 22 & 43 \\
Sama Baik & 0 & 49 \\
Lebih Buruk & & 8 \\
Kebersihan & 43 & \\
Lebih Baik & 49 & \\
Sama Baik & 8 & \\
Lebih Buruk & & \\
\hline Sumber: Data primer, diolah 2018 & & \\
& &
\end{tabular}

Tabel 2 diatas menunjukkan bahwa kualitas berdasarkan warna, sebanyak 53 orang menilai bahwa warna beras premium sama baik dengan jenis beras medium, dan 11 orang responden menilai bahwa kualitas beras premium lebih buruk dibandingkan dengan jenis beras medium, hal ini dikarenakan masih didapatkan beras premium yang berwarna kecoklatan. Berdasarkan kepulenan, sebanyak 56 orang responden menilai bahwa beras premium lebih pulen dibandingkan dengan beras jenis medium. Sedangkan 37 orang responden menilai bahwa kepulenan beras premium sama dengan beras jenis medium, dan 7 orang responden menilai bahwa kepulenan beras premium lebih buruk dibandingkan dengan beras medium, hal ini dikarenakan masalah pada cara memasak. Sebagian konsumen belum mengetahui ukuran air yang pas untuk memasak beras premium. Ini menjadi 
masukan kepada produsen agar menyertakan informasi tentang karakteristik beras dan petunjuk pemasakan jika diperlukan di kemasan.

Berdasarkan aroma, sebanyak 51 responden menilai bahwa aroma beras premium lebih baik dari beras medium. Sedangkan sebanyak 40 responden menilai bahwa aroma beras premium sama baik dengan aroma beras medium. Dan 9 orang responden menilai bahwa aroma beras premium lebih buruk dibandingkan dengan aroma beras medium, ini terjadi karena masih didapatkan beras premium yang berbau apek (kurang wangi). Berdasarkan daya tahan beras, sebanyak 41 responden menilai bahwa daya tahan beras premium lebih baik dibandingkan dengan daya tahan beras medium. Sedangkan sebanyak 47 responden menilai bahwa daya tahan beras premium sama baik dengan daya tahan beras medium, dan 12 responden menilai bahwa daya tahan beras premium lebih buruk dari beras medium. Hal ini karena masih didapatkan beras premium yang cepat bau dan muncul kutu ketika disimpan.

Berdasarkan keseragaman bulir beras, sebanyak 78 orang responden menilai bahwa keseragaman bulir beras premium lebih baik dari beras medium. Sedangkan 22 orang responden menilai bahwa keseragaman bulir beras premium sama baik dengan keseragaman bulir beras medium, dan tidak ada responden yang menilai bahwa keseragaman bulir beras premium lebih buruk dari keseragaman bulir beras medium. Berdasarkan kebersihan menunjukkan bahwa sebanyak 43 orang menilai bahwa kebersihan beras premium lebih baik dari pada beras medium. Sedangkan sebanyak 49 orang menilai bahwa kebersihan beras premium sama baik dengan beras medium, dan 8 orang responden menilai bahwa kebersihan beras premium lebih buruk dari pada beras medium, hal ini karena masih terdapat beras premium yang tercampur dengan gabah serta batu-batu kecil.

\section{c. Persepsi konsumen terhadap kepercayaan beras premium}

Penilaian persepsi konsumen terhadap kepercayaan beras premium dilakukan dengan cara mengajukan pertanyaan yang jawabannya lebih baik, sama baik, lebih buruk dibandingkan dengan kepercayaan terhadap beras medium.

Tabel 3. Penilaian Konsumen Terhadap Kepercayaan Beras Premium

\begin{tabular}{lcc}
\hline Kepercayaan & $\begin{array}{c}\text { Jumlah } \\
\text { (Orang) }\end{array}$ & $\begin{array}{c}\text { Presentase } \\
(\%)\end{array}$ \\
\hline Lebih Baik & 47 & 47 \\
Sama Baik & 42 & 42 \\
Lebih Buruk & 11 & 11 \\
Total & 100 & 100 \\
\hline
\end{tabular}

Sumber: Data primer, diolah 2018

Tabel 3 menunjukkan bahwa sebanyak 47 orang responden percaya bahwa beras premium merupakan beras dengan kualitas terbaik. Sedangkan sebanyak 42 orang responden memiliki kepercayaan yang sama antara beras premium dan beras medium. Dan 11 orang responden memiliki kepercayaan yang lebih buruk terhadap beras premium dibandingkan dengan beras medium. 11 orang konsumen yang menyatakan beras premium lebih buruk daripada beras medium karena pada saat membeli beras premium konsumen menemukan kreteria kualitas beras seperti kebersihan, aroma, keseragaman, kepulenan kurang bagus jika dibandingkan dengan medium sehingga mereka tidak yakin jika kualitas beras premium lebih baik daripada beras medium. Mayasari et al (2017) menyatakan bahwa konsumen sudah memperhatikan atribut produk seperti kemasan, harga, kebersihan, aroma, warna dan kepulenan. Produsen harus memperhatikan kualitas produk secara berkala karena kepercayaan konsumen penting dalam meningkatkan penjualan produk. Aji et al (2010) dalam penelitiannya menjelaskan bahwa kualitas beras menjadi urutan paling tinggi dalam memutuskan pembelian beras oleh konsumen.

\subsection{Karakteristik responden}

Jumlah responden dalam penelitian ini sebanyak 100 orang. Karakteristik responden yang diamati antara lain usia, pendidikan, pendapatan, pekerjaan, dan jumlah anggota keluarga. 


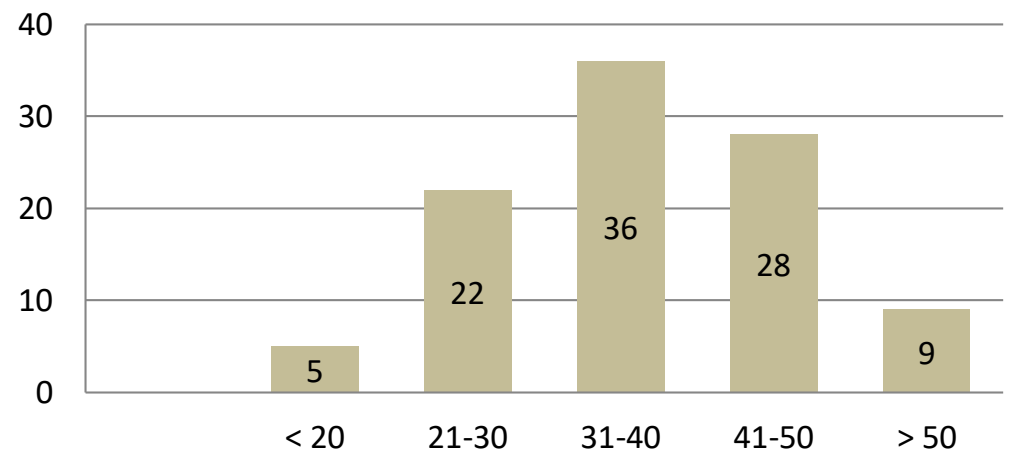

Gambar 1. Sebaran reponden berdasarkan usia

Karakteristik responden berdasarkan usia dapat dilihat pada Gambar 1, dimana usia responden sebagian besar berada pada rentang 30-40 tahun sebesar 36\%. Dari sebaran tersebut dapat dilihat bahwa usia responden merata diusia muda dan tua. Rentang usia 21-30 tahun sebesar $22 \%$ dan di rentang $41-50 \%$ sebesar $28 \%$.

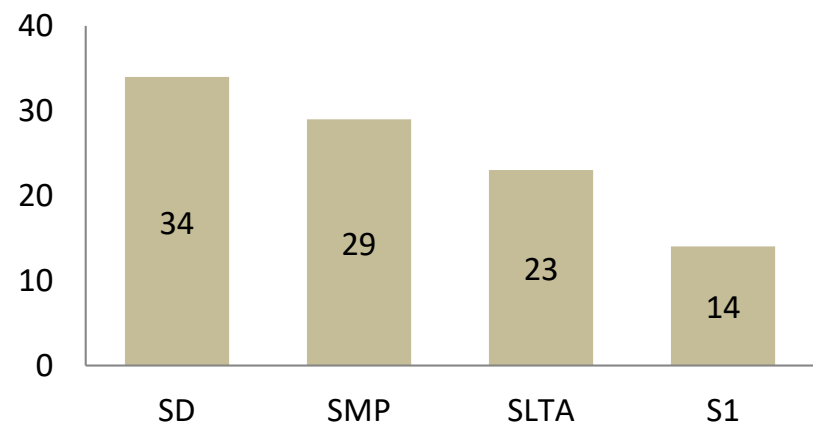

Gambar 2. Sebaran responden berdasarkan tingkat pendidikan

Sebagimana data yang disajikan pada Gambar 2, memperlihatkan bahwa tingkat pendidikan responden masih didominasi pendidikan sekolah dasar yaitu sebesar 34\%. Tingkat pendidikan akan berpengaruh terhadap keputusan pembelian beras premium karena tingkat pendidikan menentukan pengetahuan konsumen dalam membeli beras premium. Tingkat pendidikan responden tergolong rendah karena sebagian besar masih berpendidikan sekolah dasar.

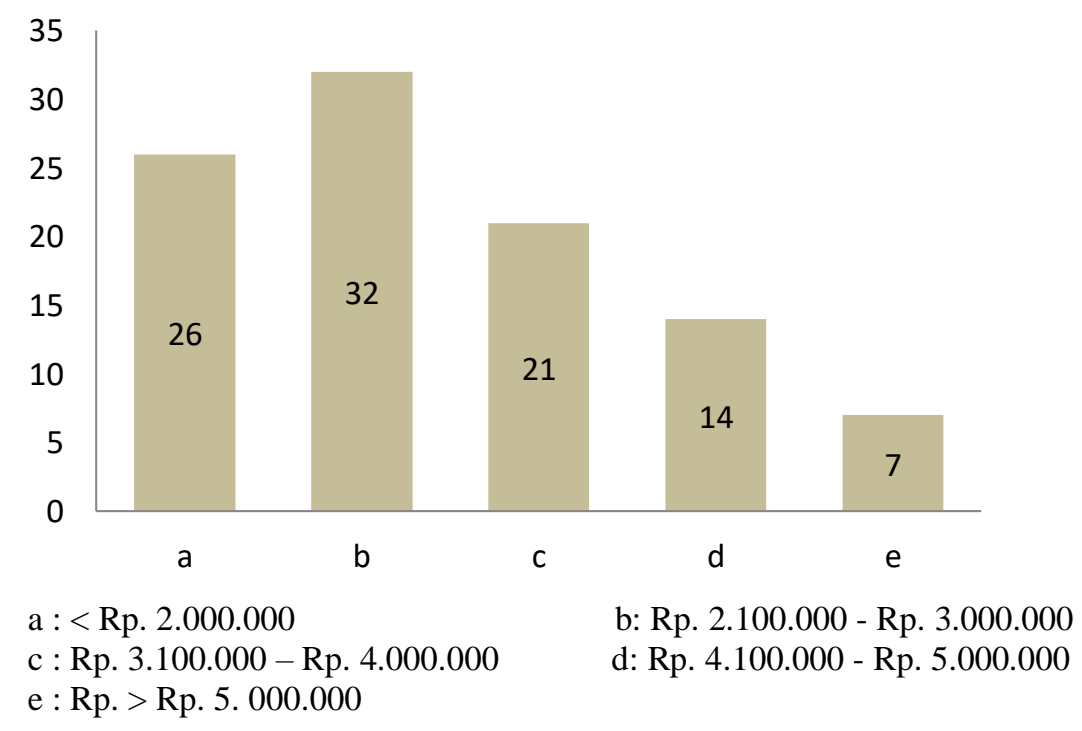

Gambar 3. Sebaran responden berdasarkan pendapatan/bulan 
Berdasarkan Gambar 3 dapat dilihat bahwa pendapatan responden paling banyak berkisaran Rp. 2.100.000 - Rp. 3.000 .000 dengan jumlah 32 orang atau $32 \%$ dari total responden. Tingkat pendapatan tentunya sangat mempengaruhi keputusan pembelian beras premium karena harga beras premium lebih tinggi daripada beras medium atau yang kualitas biasa sehingga untuk membeli konsumen harus memiliki pendapatan yang tinggi.

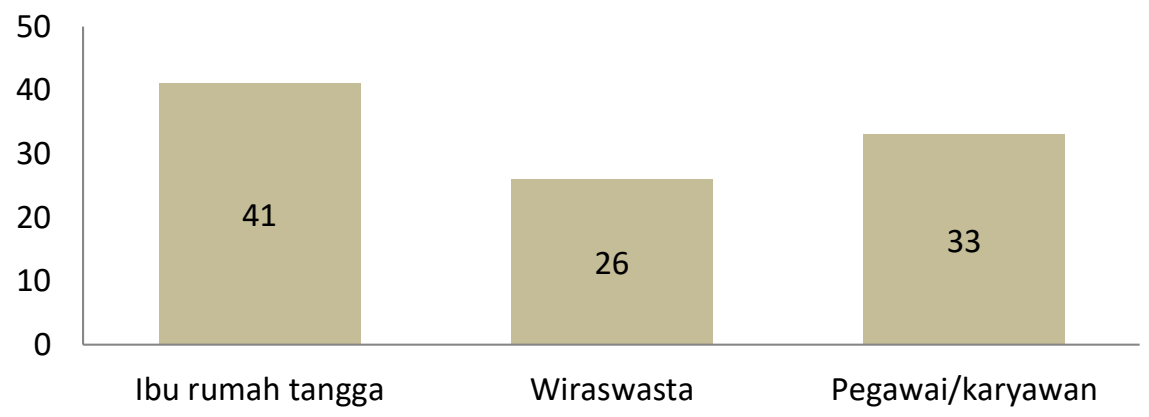

Gambar 4. Sebaran responden berdasarkan pekerjaan

Pekerjaan responden digolongkan menjadi 3 golongan yaitu : ibu rumah tangga, wiraswasta dan pegawai/karyawan. Responden yang pekerjaannya sebagai ibu rumah tangga sebanyak 41 orang, wiraswasta sebanyak 28 orang, dan responden yang pekerjaannya sebagai pegawai/karyawan sebanyak 33 orang. Dari sini dapat disimpulkan bahwa sebagian besar responden pekerjaannya sebagai ibu rumah tangga sebanyak $4141 \%$ dari total responden.

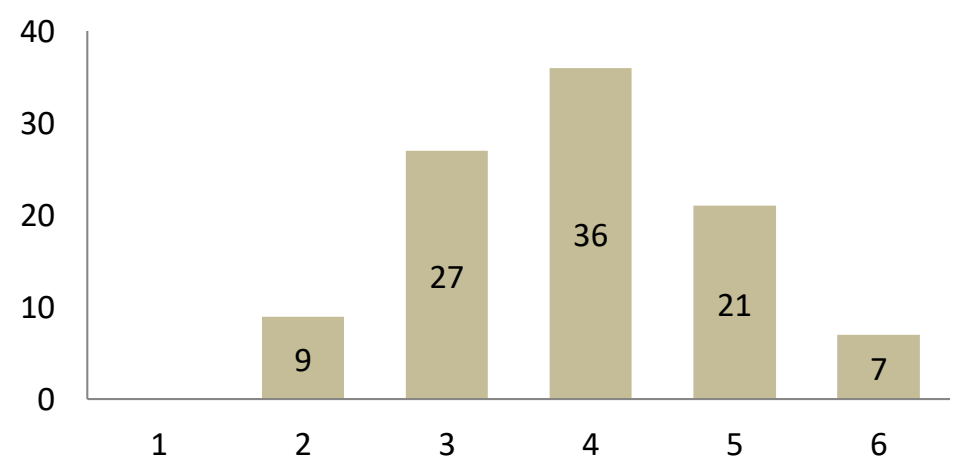

Gambar 5. Sebaran responden berdasarkan jumlah anggota keluarga

Gambar 5 menunjukkan bahwa jumlah anggota keluarga 1 orang sebanyak 0, jumlah anggota keluarga 2 orang sebanyak 9 orang responden, jumlah anggota keluarga 3 orang sebanyak 27 orang responden, jumlah anggota keluarga 4 orang sebanyak 36 orang responden, jumlah anggota keluarga 5 orang sebanyak 21 orang responden, dan jumlah anggota kelurga 6 orang sebanyak 7 orang responden. Dari sini dapat dilihat bahwa sebagian besar jumlah anggota keluarga sebanyak 4 orang. Jumlah keluarga menentukan keputusan pembelian beras premium karena semakin banyak anggota keluarga maka semakin besar jumlah beras premium yang dibeli atau konsumen beralih dengan membeli beras selain beras premium yang harganya lebih rendah.

\subsection{Faktor-faktor yang mempengaruhi keputusan pembelian beras premium}

Sebelum membahas masing-masing factor yang mempengaruhi pembelian beras konsumen, maka perlu dilihat apakah model Logit pembelian beras premium fit (sesuai) atau tidak. Hasil analisis model Logit factor-faktor yang mempengaruhi pembelian beras premium dapat dilihat pada Tabel 4 dan 5 .

Tabel 4. Hasil Analisis Hosmer-Lemeshow tes.

\begin{tabular}{lccc}
\hline Step & Chi-square & df & Sig. \\
\hline 1 & 4.093 & 8 & .849 \\
\hline Sumber : Analisis data primer 2018, diolah & &
\end{tabular}


Hasil uji nilai probabilitas Hosmer and Lemeshow's Goodness of Fit Test adalah 0,849 dimana nilai ini lebih besar dari $0,05(\alpha=5 \%)$, berarti model mampu memprediksi nilai observasinya atau dapat dikatakan model dapat diterima karena cocok dengan data observasinya (model fit).

Tabel 5. Hasil Model Summary.

\begin{tabular}{lccc}
\hline Step & -2 Log likelihood & Cox \& Snell R Square & Nagelkerke R Square \\
\hline 1 & $41.621^{\mathrm{a}}$ & .585 & .805 \\
\hline Sumber : Analisis data primer 2018, diolah &
\end{tabular}

Nilai Negelkerke $\mathrm{R}$ Square sebesar 0,805. Nilai Negelkerke R Square menunjukan nilai koefisien determinasi. Nilainya Nilai Negelkerke $\mathrm{R}$ Square 0,805 yang artinya $80,5 \%$ variabel independent memberikan pengaruh terhadap terhadap variabel dependen, dan sisanya dipengaruhi oleh variabel lainnya. Uji likelihood penelitian ini menunjukkan nilai $-2 \log$ likelihood pada block $=0$ bernilai 87,869 dan nilai pada block $=1$ bernilai 41,621 sehingga dapat dikatakan bahwa model yang dihipotesiskan fit (sesuai). Setelah model fit, maka pembahasan selanjutnya adalah apakah masing-masing variable pembelian beras premium berpengaruh signifikan terhadap pembelian beras premium. Hasil analisis factor-faktor yang mempengaruhi pembelian beras premium dapat dicermati pada Tabel 6.

Tabel 6. Hasil analisis model Logit faktor-faktor yang mempengaruhi pembelian beras premium.

\begin{tabular}{lrccc}
\hline Variabel & Koefisien & Wald & Sig. & Exp $\beta$ \\
\hline Harga $\left(\mathrm{x}_{1}\right)$ & $\mathbf{4 . 8 5 1}$ & $\mathbf{4 . 8 9 6}$ & $\mathbf{0 . 3 1 3 5}$ & 127.863 \\
Usia/umur $\left(\mathrm{x}_{2}\right)$ & 0.064 & 1.392 & 0.238 & 1.066 \\
Pendidikan $\left(\mathrm{x}_{3}\right)$ & $\mathbf{0 . 6 9 2}$ & $\mathbf{1 1 . 7 0 4}$ & $\mathbf{0 . 0 0 1}$ & 1.997 \\
Pendapatan $\left(\mathrm{x}_{4}\right)$ & $\mathbf{0 . 0 9 1}$ & $\mathbf{6 . 1 9 9}$ & $\mathbf{0 . 0 1 3}$ & 1.095 \\
Jumlah anggota keluarga $\left(\mathrm{x}_{5}\right)$ & $\mathbf{- 3 . 2 0 1}$ & $\mathbf{1 5 . 5 2 1}$ & $\mathbf{0 . 0 0 0}$ & 0.041 \\
Persepsi konsumen $\left(\mathrm{x}_{6}\right)$ & 0.789 & 0.576 & 0.448 & 2.201 \\
constant & 6.420 & 4.113 & 0.043 & 0.002 \\
\hline
\end{tabular}

Sumber : Analisis data primer 2018, diolah

Mengacu pada Tabel 6 dapat dilihat bahwa ada 3 faktor yang berpengaruh terhadap pembelian beras premim. Faktor tersebut adalah pendidikan, pendapatan dan jumlah keluarga. Faktor usia dan persepsi konsumen tidak berpengaruh terhadap variabel dependen. Berikut adalah pembahasan masing-masing variable pembelian beras premium.

1. Harga $\left(\mathrm{x}_{1}\right)$

Harga beras tidak berpengaruh signifikan terhadap keputusan pembelian beras. Konsumen beranggapan bahwa harga beras premium sepadan dengan kualitas beras yang diterima, ini jika dibandingkan dengan beras curah. Harga tidak menjadi faktor penting dalam keputusan pembelian beras. Prafithriasari et al (2020) juga menyatakan bahwa harga beras tidak berpengaruh terhadap minat beli konsumen. Harga beras premium di lokasi penelitian rata-rata Rp.12.000 per $\mathrm{kg}$. Hal ini bertentangan dengan pendapat Tarigan et al (2013) bahwa jika harga beras mengalamai kenaikan maka konsumen akan menurunkan pembeliannya. Triyana (2019) menyatakan bahwa konsumen di kota Lubuklinggau menilai harga beras premium ditahun tersebut cukup tinggi yaitu rata-rata Rp. 11.262,5 per kg dan konsumen bersedia membeli beras premium dengan harga Rp. 10.188 per kg. Beberapa penelitian juga menyatakan bahwa harga beras perpengaruh terhadap keputusan pembelian beras ( Ikasari et al, 2016; Gunarso et al, 2017; AF et al, 2018; Putriani et al, 2019).

\section{Usia/umur $\left(\mathrm{x}_{2}\right)$}

Usia menunjukkan kematangan berfikir atau kedewasaan dalam mengambil keputusan. Usia yang lebih tua menunjukkan kedewasaan dan kematangan mengambil keputusan lebih tinggi dibandingkan yang lebih muda, karena usai yang lebih tua dianggap lebih berpengalaman dalam mengaruhi kehidupan. Usia konsumen tidak berpengaruh terhadap keputusan pembelian beras premium. Usia konsumen hampir merata yaitu antara 20 - lebih dari 50 tahun, namun rentang terbesar berada pada usia 21 - 50 tahun. Inilah yang menyebabkan variabel usia tidak berpengaruh terhadap keputusan pembelian. 


\section{Pendidikan $\left(\mathrm{x}_{3}\right)$}

Tingkat pendidikan berhubungan dengan ilmu pengetahuan dan wawasan yang dimiliki oleh responden. Tingkat pendidikan menunjukkan kualitas pola pikir sumber daya manusia. Semakin tinggi tingkat pendidikan responden akan lebih mudah dalam menerima dan merespon informasi atau teknologi baru. Hasil analisis menunjukkan bahwa tingkat pendidikan berpengaruh signifikan terhadap keputusan pembelian beras premium. Konsumen yang berpendidikan lebih tinggi akan membeli beras premium. Tingkat pendidikan konsumen responden sebagian besar berpendidikan sekilah dasar (SD), sedangkan yang berpendidikan SMP, SMA dan sarjana kurang dari 30\%. Dengan hasil analisis ini menunjukkan bahwa responden yang berpendidikan SMA dan sarjana memiliki potensi atau peluang lebih besar dalam memutuskan pembelian beras premium.

\section{Pendapatan $\left(\mathrm{x}_{4}\right)$}

Pendapatan responden adalah total pendapatan yang diperoleh selama satu bulan. Hasil analisis menunjukkan bahwa pendapatan berpengaruh positif dan siginifikan terhadap keputusan pembelian beras premium. Ini artinya bahwa reponden yang berpendapatan tinggi akan memutuskan membeli beras premium. Rata-rata pendapatan responden terbesar berkisar antara Rp. 2.100 .000 - Rp. 3.000.000, dan responden yang berpendapatan diatas Rp.4.000.000 sebanyak 21 orang. Dan menurut survey responden yang memiliki pendapatan diatas 4 juta lebih memilih membeli beras premium. Rahmi et al. (2019) menyatakan bahwa pendapatan masyarakat berpengaruh terhadap tingkat konsumsi beras. Aji et al. (2010) berpendapat bahwa konsumen beras terbagi menjadi masyarakat yang berpendapatan menengah kebawah dan tinggi, masyarakat sebagian besar masih memilih mengkonsumsi beras yang murah dengan kualitas yang kurang bagus. Darsan (2018) menyatakan bahwa pendidikan berpengaruh terhadap keputusan pembelian beras.

\section{Jumlah anggota keluarga $\left(\mathrm{x}_{5}\right)$}

Jumlah anggota keluarga adalah jumlah orang yang berada dalam keluarga tersebut yang kebutuhan hidupnya menjadi tanggungan kepala keluarga. Jumlah anggota keluarga berpengaruh negatif signifikan terhadap keputusan pembelian beras premium, artinya jika jika jumlah anggota keluarga bertambah konsumen mengurungkan niatnya untuk membeli beras premium. Jumlah anggota keluarga responden sebagian besar adalah 4 orang. Jumlah anggota keluarga yang besar artinya kebutuhan akan beras lebih besar, sehingga pengeluaran untuk pembelian beras juga akan lebih besar jika dibandingkan dengan jumlah anggota keluarga yang lebih sedikit. Darsan (2018) menyatakan bahwa jumlah anggota keluarga berpengaruh terhadap keputusan pembelian beras.

6. Persepsi konsumen terhadap beras premium $\left(\mathrm{x}_{6}\right)$

Persepsi konsumen ini meliputi pendapat konsumen terhadap kualitas beras premium (Kepulenan, warna, daya tahan, keseragaan bulir, aroma dan kebersihan). Persepsi konsumen tidak berpengaruh signifikan terhadap keputusan pembelian beras. Ini disebabkan bahwa konsumen sebenarnya memiliki perspesi yanng baik terhadap kualiats beras premium namun bukan menjadi fakror penting untuk memutuskan pembelian beras premium. Mereka masih memikirkan pendapatan dan jumlah anggota keluarga yang menjadi tanggungannya. Yusuf et al. (2018) menambahkan bahwa pendapatan tidak memiliki hubungan dengan sifat fisik beras. Ini artinya bahwa konsumen lebih mempertimbangkan pendapatan dari pada kualitas fisik beras dalam pembelian beras.

\section{KESIMPULAN}

Penelitian ini menjelaskan secara diskriptif persepsi konsumen terhadap beras premium dan menganalisis factor-faktor yang mempengaruhi pembelian beras premium. Penelitian dilakukan di Pasuruan, Jawa Timur. Sampel penelitian adalah konsumen beras premium sebanyak 100 orang ditentukan melalui convenience sampling. Metode analisis data menggunakan analisis deskripsi tabulasi dan regresi model Logit. Dapat disimpulkan bahwa konsumen memiliki persepsi yang baik terhadap beras premium, terlihat pada beberapa indikator kualitas beras premium seperti kepulenan, warna, aroma, daya tahan, keseragaman bulir dan kebersihan yang di amati sebagian besar konsumen menyatakan kepuasannya terhadap beras premium. Faktor-faktor yang menjadi penentu konsumen memutuskan membeli beras premium adalah pendidikan, pendapatan dan jumlah anggota keluarga. 
Produsen beras premium perlu memperhatikan beberapa variabel yang berpengaruh terhadap keputusan konsumen dalam membeli beras premium dan selalu memperhatikan kualitas beras.

\section{DAFTAR PUSTAKA}

AF, D. S., \& Nangameka, Y. (2018). Analisis Faktor-Faktor Yang Mempengaruhi Perilaku Konsumen Dalam Pembelian Beras IR 64 di Pasar Tradisional (Studi Kasus Di Pasar Tradisional Kecamatan Panji Kabupaten Situbondo). AGRIBIOS, 16(2), 39-48.

Aji, J. M. M., \& Widodo, A. (2010). Perilaku Konsumen Pada Pembelian Beras Bermerk Di Kabupaten Jember Dan Faktor Yang Mempengaruhinya. JSEP (Journal of Social and Agricultural Economics), 4(3), 12-24.

BPS (Badan Pusat Statistik). 2017. Kajian Konsumsi Bahan Pokok 2017. Jakarta

Badan Standarisasi Nasional (BSN). 2015. Standar Nasional Indonesia Beras. SNI 6128:2015. Badan Standarisasi Nasional, Jakarta.

Darsan, I. (2018). Analisis Faktor-Faktor Yang Mempengaruhi Kepercayaan Konsumen Terhadap Keputusan Pembelian Beras Terate Di Kecamatan Bojonegoro (Studi Kasus Di Kecamatan Bojonegoro Kabupaten Bojonegoro). Oryza-Jurnal Agribisnis Dan Pertanian Berkelanjutan, 4(1), 1-12.

DeMaris, A. (1992) Logit Modeling: Practical Applications. Sage Publications Newbury Park-London. New Delhi.

Gunarso, K. (2017). Analisis Pengaruh Kualitas Produk, Harga Dan Kesadaran Merek Terhadap Keputusan Pembelian Beras Premium Dengan Minat Beli Sebagai Variabel Intervening. Jurnal Manajemen dan Bisnis, 5(3).

Ikasari, D. M., Deoranto, P., Silalahi, R. L. R., \& Citraresmi, A. D. P. (2016). Analisis faktor-faktor yang mempengaruhi perilaku konsumen dalam pengambilan keputusan pembelian beras organik. Jurnal Teknologi Pertanian, 17(1), 69-78.

Khoiriyah, N., Anindita, R., Hanani, N., \& Muhaimin, A. W. (2020). IMPACTS OF RISING ANIMAL FOOD PRICES ON DEMAND AND POVERTY IN INDONESIA. Agricultural Socio-Economics Journal, 20(1), 65-76.

Mayasari, N. A. Sikap Dan Keterlibatan Konsumen Dalam Keputusan Pembelian Beras Di Pasar Modern Kota Surakarta. Jurnal Agrista, 5(1).

Mufidah, R. A., Budiraharjo, K., \& Sumarjo, D. (2019). Pengaruh Kualitas Dan Harga Terhadap Volume Penjualan Beras Premium Perum Bulog Sub Divisi Regional Wilayah V Kedu. Mediagro, 14(2).

My, N. H., Rutsaert, P., Van Loo, E. J., \& Verbeke, W. (2017). Consumers' familiarity with and attitudes towards food quality certifications for rice and vegetables in Vietnam. Food Control, 82, 74-82.

Nikmatul, K., Ratya, A., Nuhfil, H., \& Wahib, M. A. (2020). The analysis demand for animal source food in Indonesia: Using Quadratic Almost Ideal Demand System. Business: Theory and Practice, 21(1), 427-439. https://doi.org/10.3846/btp.2020.

Prafithriasari, M., \& Nirmawati, S. (2020). Analisis Minat Beli Konsumen Terhadap Beras Berdasarkan Pengaruh Harga, Kualitas Produk Dan Kemasan Di Pb. Jembar Ati Cianjur. Agrita (Agri), 1(1), 84-102.

Prakarsa, Yudi., Sumarwan, Ujang., dan Bawono, Sri. 10 Desember 2010. Analisis Pengaruh Butir Patah dan Menir Terhadap Penjualan Beras Premium Di Pasar Induk Beras Cipinang.Bogor.Institut Pertanian Bogor.

Puspitasari, I., Sumampouw, H. J., \& Punuindoong, A. Y. (2018). Pengaruh Kualitas Produk Dan Kesesuaian Harga Terhadap Peningkatan Penjualan Beras Premium Pada Perum Bulog Divisi Regional Sulawesi Utara Dan Gorontalo (Studi Kasus Pada Konsumen Wilayah Kota Manado). Jurnal Administrasi Bisnis, 6(002).

Putriani, R. A. P., Mulyana, A., \& Bidarti, A. (2019). Faktor-Faktor Yang Mempengaruhi Keputusan Konsumen Dalam Pembelian Beras Premium Pasca Penetapan Harga Eceran Tertinggi (Ceiling Retail Price) Di Pasar Tradisional Kecamatan Muara Enim Kabupaten Muara Enim (Doctoral Dissertation, Sriwijaya University). 
Rahmawati, 2013. Analisis Faktor-faktor yang Mempengaruhi Keputusan Konsumen Dalam Pembelian Beras di Kecamatan Wonosari (Tesis Tidak Dipublikasikan).

Rahmi, F. D. Faktor-Faktor Yang Mempengaruhi Konsumsi Beras Rumah Tangga Di Kecamatan Sumbersari Kabupaten Jember (Doctoral Dissertation, Fakultas Pertanian Universitas Jember).

Tarigan, E. B., \& Kusbiantoro, B. (2015). Pengaruh derajat sosoh dan pengemas terhadap mutu beras aromatik selama penyimpanan.

Triyana, E., Mulyana, A., \& Thirtawati, T. (2019). Analisis Perilaku Konsumen Beras Premium Dan Tingkat Kepuasan Konsumen Di Kota Lubuklinggau (Doctoral Dissertation, Sriwijaya University).

Wahyudin, W. (2019). Pengaruh Persepsi Konsumen Mengenai Harga, Lokasi, Dan Kualitas Pasar Terhadap Minat Beli Konsumen Di Pasar Pon Purwokerto. Jurnal Pendidikan Dan Ekonomi, 8(2), 142-149.

Yusuf, Y., Amrullah, A., \& Tenriawaru, A. N. (2018). Perilaku Konsumen Pada Pembelian Beras Di Kota Makassar (Cunsomer Behavior on Purchasing Rice in Makassar City). Jurnal Sosial Ekonomi Pertanian, 14(2), 105-120. 